\title{
Tree-ring-based temperature reconstruction for the Wolong Natural Reserve, western Sichuan Plateau of China
}

\author{
Zongshan $\mathrm{Li}{ }^{\mathrm{a}}$ Guohua Liu, ${ }^{\mathrm{a} *}$ Xing $\mathrm{Wu}^{\mathrm{a}}$ and Xiaochun Wang ${ }^{\mathrm{b}}$ \\ ${ }^{a}$ State Key Laboratory of Urban and Regional Ecology, Research Center for Eco-Environmental Science, Chinese Academy of Sciences, \\ Beijing, China \\ ${ }^{\mathrm{b}}$ College of Forestry, Northeast Forestry University, Harbin, China
}

\begin{abstract}
High-resolution tree-ring records covering past centuries in the western Sichuan Plateau of China are scarce, yet essential for developing a complete understanding of the regional patterns of climate change for the Tibetan plateau. This paper presents a temperature reconstruction for the Wolong Natural Reserve of the western Sichuan Plateau based on a tree-ring width chronology of a cypress species (Sabina saltuaria) endemic to the Tibetan plateau. The annual (prior October to current September) temperature reconstruction, which spans from 1840 to 2011, was developed using a linear regression model. The reconstruction explains $54.1 \%$ of the actual temperature variance during the calibration period from 1956 to 2010 . The noteworthy warming periods of the reconstruction occurred between 1864-1882 and 1927-1960, while the most pronounced cold episodes were found between 1886-1926, 1788-1822, and 1961-1996. Spectral analysis revealed the existence of multi-decadal, decadal, and annual cycles that might correspond to the related cycles of Atlantic Multidecadal Oscillation, solar activity, and ENSO-type variability, respectively.
\end{abstract}

KEY WORDS temperature reconstruction; tree-ring width; Sabina saltuaria; western Sichuan Plateau

Received 11 October 2013; Revised 12 October 2014; Accepted 15 October 2014

\section{Introduction}

Knowledge of climate conditions over past centuries is indispensable in determining whether modern climate change is unprecedented in a pre-industrial context, and adds the benefit of allowing the anticipation of the probability of future episodes (Mann et al., 2008; Cook et al., 2010; Marcott et al., 2013; Stern and Kaufmann, 2014). Development of this understanding is hindered by instrumental measurements that usually cover only the last 50-100 years. This necessitates the use of natural climate archives such as tree rings to capture climate information in the context of longer time scales (Fritts, 1976; Schweingruber, 1996). Conditions on the Tibetan Plateau, one of the Earth's most imposing geomorphic features, have catalysed a considerable body of research in dendroclimatology, with a series of climate reconstructions having been built (Zhang et al., 2003; Liang et al., 2008; Yang et al., 2009; Shao et al., 2010; He et al., 2013; Wang et al., 2014). Those studies have enabled the successful reconstruction of the 3500-year tree-ring record of annual precipitation on the northeastern Tibetan Plateau (Yang et al., 2014). Key gaps in our understanding of climate change for the Tibetan Plateau still remain, primarily due to sparse coverage of tree-ring sample sites,

\footnotetext{
* Correspondence to: G.-H. Liu, State Key Laboratory of Urban and Regional Ecology, Research Center for Eco-Environmental Science, Chinese Academy of Sciences, Beijing 100085, China. E-mail: ghliu@rcees.ac.cn
}

despite intensified recent efforts (Cook et al., 2010; Yang et al., 2010, 2014). Improved knowledge of these efforts is still needed to create additional climate reconstructions on the Tibetan plateau for regions without sufficient tree-ring data, such as the western Sichuan Plateau.

The western Sichuan Plateau consists of the southeastern part of the Tibetan Plateau (Liu et al., 2001; Fu et al., 2004). Several climate systems, i.e. the eastern Asian monsoon, the Indian monsoon, and the continental westerlies, play an active role in driving the regional climate patterns of this region (Song et al., 2006). This region is largely covered by alpine coniferous forests and tree-ring data from those forests at the upper elevation limit should ideally serve as high-resolution evidence of past climate variation (Figure 1). Based on the living spruce (Picea balfouriana) trees of Shanuli Mountain, Shao and Fan (1999) developed a 345-year winter temperature reconstruction, which is the first climate reconstruction based on tree rings in this region. Significant progress has been made recently in deriving annually resolved estimates of climatic fluctuations derived from tree-ring data in west Sichuan, and several tree-ring-based temperature reconstructions from various geographical sites of this region are available (Song et al., 2007; Qin et al., 2008; Wu et al., 2008; Li et al., 2011a; Yu et al., 2012). In comparison to the nearby Tibetan Plateau (Bräuning, 2001; Yang et al., 2003, 2009, 2010; Zhang et al., 2003; Liang et al., 2008; Fan et al., 2010; Shao et al., 2010; He et al., 2013; Wang et al., 2014), however, the western Sichuan Plateau still receives little attention and only a limited set 


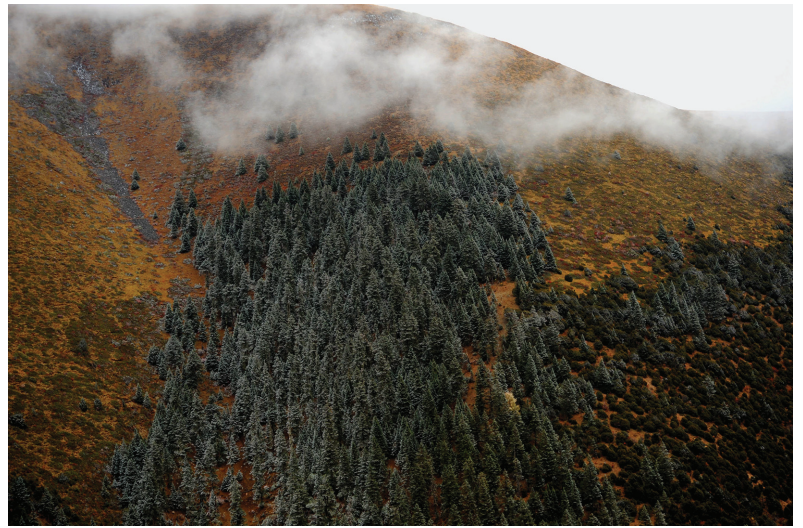

Figure 1. A typical treeline site of coniferous forests in the western Sichuan plateau of China (Photographed by Guohua Liu).

of tree-ring chronologies have been built (Qin et al., 2008; Wu et al., 2008; Yu et al., 2012). Increased efforts to obtain new tree-ring archives from the western Sichuan Plateau are recommended to improve our understanding of the spatial and temporal details of climatic variations for this region.

We developed a new tree-ring width chronology for a cypress species (Sabina saltuaria) in the Wolong Natural Reserve, in the western Sichuan Plateau of China. The goals of this study are to (1) investigate the climatic response of the new chronology and reconstruct the temperature history of the past 172 years, (2) use various climate proxy records to validate this reconstructed temperature series within a confined region, and finally (3) detect the significant cycles and related climatic fingerprints of the reconstruction.

\section{Materials and methods}

\subsection{Study area}

The Wolong Natural Reserve is located in the eastern portion of the western Sichuan Plateau, which acts as a transition zone from the Chengdu Plain to the Tibetan Plateau. The reserve has a territory of $2000 \mathrm{~km}^{2}\left(102.87^{\circ}-103.4^{\circ} \mathrm{E}\right.$, $30.75^{\circ}-31.42^{\circ} \mathrm{N}$, Figure 2(a)) (An et al., 2001) and was established as a biosphere reserve within the reserve network of UNESCO's Man and Biosphere program in 1980 (Fu et al., 2004). The reserve was established to protect alpine and sub-alpine ecosystems and endangered species such as giant pandas (Ailuropoda melanoleuca), golden monkeys (Rhinopithecus roxellanae), and dove trees (Davidia involucrata) (Liu et al., 2001; Fu et al., 2004). The reserve, which includes contrasting topographic conditions, ranges in elevation from 1200 to $6250 \mathrm{~m}$ (Taylor et al., 1991). Within the reserve, mountain peaks are generally above $5000 \mathrm{~m}$ a.s.1., e.g. Balang Mountain $\left(102.9^{\circ} \mathrm{E}, 30.93^{\circ} \mathrm{N}, 5040 \mathrm{~m}\right.$ a.s.1.) and Four Girls Mountain $\left(102.9^{\circ} \mathrm{E}, 31.11^{\circ} \mathrm{N}, 6250 \mathrm{~m}\right.$ a.s.1.). The Pitiao River runs through the reserve and flows into the Min River (the first tributary of the Yangtze River) (Figure 2(b)). The vegetation within the reserve includes evergreen broadleaf, deciduous, and sub-alpine coniferous forests, as well as alpine meadows along lower to upper elevation gradients (He et al., 2009). Soils are predominantly sandstone, shale, and limestone derived from sedimentary and metamorphic parent materials. Soil depth varies with slope and is deepest on gently sloping plateaus and shallowest on steep slopes (Taylor and Qin, 1988).

Lying in the eastern climatic zone of the Tibetan Plateau, the reserve is characterized by a temperate sub-humid climate (Cui et al., 2005). In the winter months (from November to April), the main climate determinants are the continental air masses, resulting in sunny and dry weather. By contrast, the climate during the summer months (from May to October) is primarily influenced by the southeastern Asian monsoon, causing warm-wet conditions. Data from the Desheng Ecological Station within the reserve $\left(2730 \mathrm{~m}, 102.97^{\circ} \mathrm{E}, 30.85^{\circ} \mathrm{N}\right.$; Figure 2(b)) (Liu et al., 2006), located near our sample site, exemplify the local climate. Mean annual temperature is $8.4^{\circ} \mathrm{C}$. Mean monthly minimum (January) and maximum (July) temperatures are approximately -1.7 and $17.0^{\circ} \mathrm{C}$, respectively. The mean annual precipitation is approximately $900 \mathrm{~mm}$, and the rainy season (May-October) accounts for approximately $80 \%$ of the total annul precipitation. The mean frost-free period is of approximately 190 days. The time from mid-May to late September approximately corresponds to the growing season (Song et al., 2006).

\subsection{Study materials}

S. saltuaria is endemic to China and is distributed at the southeastern portion of the Tibetan plateau. S. saltuaria usually occurs as a dominant constituent of treeline vegetation (Zhang et al., 2007). It is commonly found in the elevation zone between 3600 and $4000 \mathrm{~m}$, where it forms dense stands of krummholz or sparse tree forests. On the Sejila Mountain of eastern Tibet, $S$. saltuaria is distributed in elevations between 4320 and $4520 \mathrm{~m}$ on the south-facing slopes. This should be the highest elevation zone in which this species grows (Guo et al., 2010). The presence and dominance of $S$. saltuaria at the treeline sites depend on its extreme tolerance to the climate conditions, such as freezing damage, winter desiccation, and ice blast (Körner, 1998; Zhang et al., 2007).

The $S$. saltuaria forest study site in the Wolong Natural Reserve, approximately $3 \mathrm{~km}$ southeast of the Dengsheng ecological station (Figure 2(b)), is located on the south-facing slope. In this stand, $S$. saltuaria trees have a relatively narrow elevation range (from 3600 to $3700 \mathrm{~m}$ ) and make up the treeline ecotone. $S$. saltuaria is associated with Quercus semicarpifolia and Rhododendron spp. and is found growing as sparse forest landscape. Our S. saltuaria sampling site $\left(3700 \mathrm{~m}, 102.99^{\circ} \mathrm{E}, 30.85^{\circ} \mathrm{N}\right)$ is close to its upper elevation limit, and trees can reach approximately $15 \mathrm{~m}$ with an average diameter of about $50 \mathrm{~cm}$ at breast height (Figure 2(c)).

\subsection{Sampling and preparation}

Increment cores, usually two from each living S. saltuaria tree, were taken approximately at $1 \mathrm{~m}$ height using Haglof 

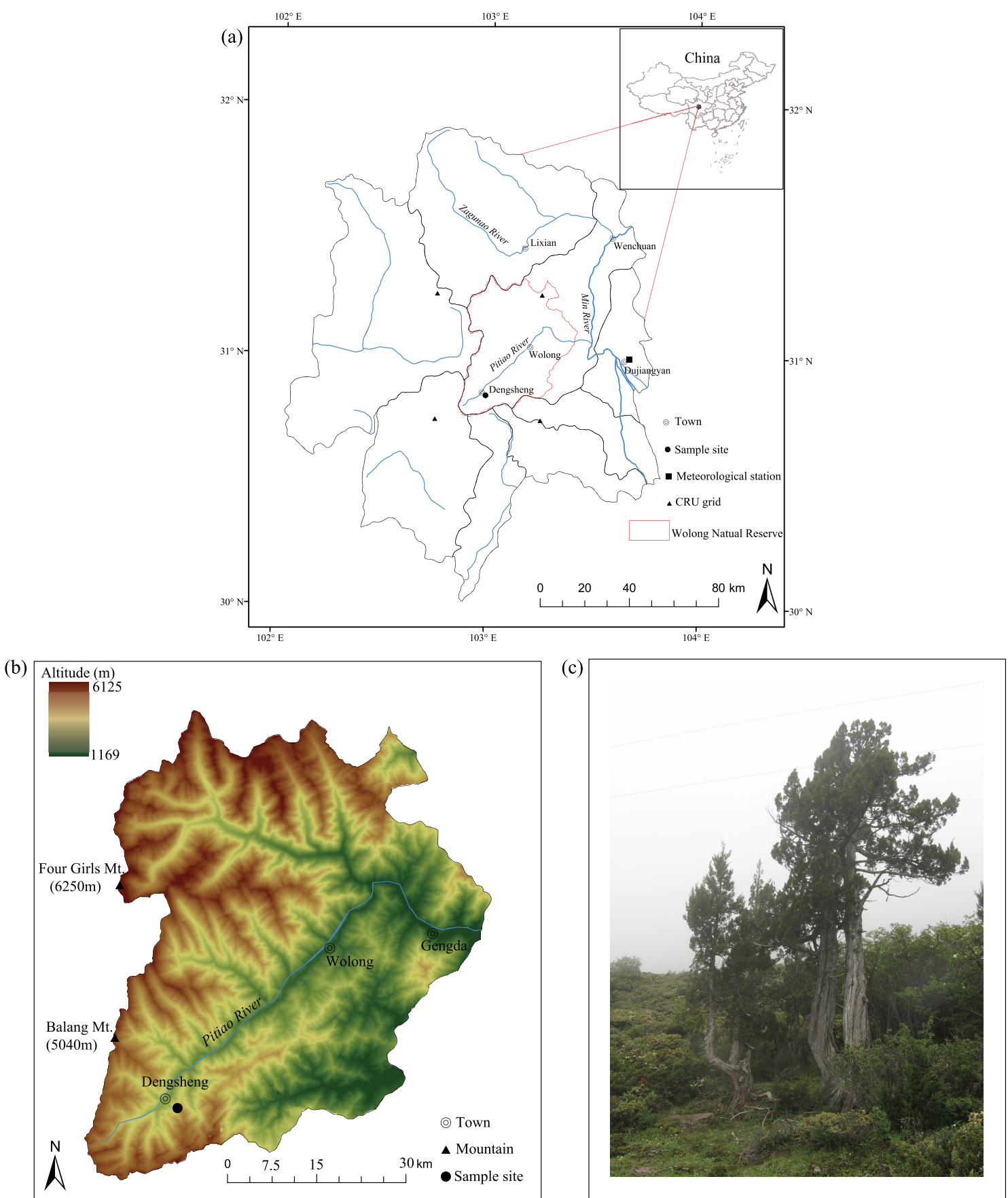

Figure 2. Location map of Wolong Natural Reserve (WNR), southwestern China. (a) Map of the tree-ring sample site, meteorological station, and CRU gridded climate data points in WNR and its adjoined regions; (b) Topographic map of WNR showing sampling site, rivers, and mountain ranges; (c) Autumn view of $S$. saltuaria trees in the study site targeted for sampling (Photographed by Songlin Shi).

increment borers (Grissino-Mayer, 2003). After extraction, all samples were stored in plastic straws and appropriately labelled. In total, 70 cores from 35 S. saltuaria trees were collected. Sampling at the study site was completed in the autumn of 2012. In the laboratory, samples were air dried and mounted on slotted wooden boards, and then polished with progressively finer sandpaper (from 240-grid to 600 -grid) to reveal individual cell boundaries (Orvis and Grissino-Mayer, 2002). The widths of all rings of each core were measured to $0.001 \mathrm{~mm}$ on a Lintab tree-ring station (Rinntech Inc., Heidelberg, Germany). We further used COFECHA, a computer program that uses segmented time-series correlation techniques, to check the quality of visual crossdating (Holmes, 1983). Finally, 62 cores of 31 trees were crossdated successfully.

\subsection{Chronology development}

The crossdated tree-ring data were standardized using the ARSTAN program (Cook and Kairiukstis, 1990). Standardization converts the ring widths into dimensionless indices, removes age-growth trends, and allows the raw data to be averaged into a single index chronology. The raw 
data were conservatively detrended using linear regression lines or negative exponential curves. A cubic spline with a $50 \%$ frequency-response cut-off equal to $67 \%$ of the series length was used in a few cases (two series) when the significant growth reversal at the ends of the series resulted in poor curve fits based on the conservative methods. The measured values were divided by the 'growth' curve values to produce a detrended and standardized series. Ring-width chronology was calculated using a mean-value function (combining the detrended tree-ring series), and the mean of each year was computed as a biweight robust estimate (Cook and Kairiukstis, 1990). To reduce the potential influence of the changing sample depth, the variance of the chronology was also stabilized using the method described by Osborn et al. (1997). Three different outputs were created: standard (STD), residual (RES), and ARSTAN (ARS). Because the standard chronology can maximize low- to high-frequency common variance, presumably in response to climate, we chose it to analyse the consistency of the climate response.

We also calculated several descriptive statistics pertaining to the chronology generated by the COFECHA and ARSTAN programs: expressed population signal (EPS), average inter-series correlation (Rbar), mean sensitivity (MS), signal-to-noise ratio (SNR), first-order serial autocorrelation (AC1), and the variance in the first eigenvector (VFE). The EPS statistics was calculated to represent the variance agreement between a finite sample size and a theoretical infinite sample size. Though a specific range of EPS values of acceptable statistical quality cannot be given, Wigley et al. (1984) suggested a threshold of 0.85 as reasonable. Rbar is a measure of how well the samples within a chronology correlate. A high Rbar suggests accurate crossdating and a common signal, likely a regional climate response (Grissino-Mayer, 2001). Both EPS and Rbar were calculated in a 30-year running window with 15-year overlaps along the chronology. MS reflects year-to-year change in tree growth. Samples from a site with a high MS have considerable variation in ring width, while those from a site with low MS are complacent and unlikely to exhibit a strong climate response (Fritts, 1976). AC1 determines if biological persistence is an issue in the chronology. SNR is used to detect the high-frequency variation of tree-ring width series, and VFE to estimate the strength of observed common signals among the trees.

\subsection{Data analysis}

Although the Dengsheng ecological station is the nearest climate station to the sample site (approximately $3 \mathrm{~km}$ from the study site), the extremely limited and incomplete meteorological records (available only from 1999 to 2008) make it difficult to perform reliable calibration with the targeted tree-ring data. Consequently, the chronology is compared to climate data of high quality (1956-2010) from the national meteorological station (Dujiangyan station, $698 \mathrm{~m}$ ) closet to our sample site. The data set consist of monthly mean temperature (TEM), monthly total precipitation (PRE), monthly minimum
(TMN), and maximum (TMX) temperatures. We further used gridded climate data for analyses because they provide a more regional signal than the station records do. The gridded climate data included monthly mean (TEM), minimum (TMN) and maximum (TMX) temperatures and monthly total precipitation (PRE), which were obtained from the Climatic Research Unit (CRU), East Anglia, UK (http://www.cru.uea.ac.cn: $0.5^{\circ} \times 0.5^{\circ}$; CRUts2.1; Mitchell and Jones, 2005). Mean values were calculated from four grid-boxes covering the region between $20.75^{\circ}-31.25^{\circ} \mathrm{N}$ and $102.75^{\circ}-103.25^{\circ} \mathrm{E}$ over the 1950-2002 period. In addition, the climate data used in this study included the monthly Palmer Drought Severity Index (PDSI) data developed by Dai et al. (2004). The PDSI data set covering 1950-2005 is available on a $2.5^{\circ} \times 2.5^{\circ}$ grid. The grid point $\left(28.75^{\circ} \mathrm{N}, 101.25^{\circ} \mathrm{E}\right)$ nearest to our sampling site was used in this study.

We used correlation and response function analyses to determine which climate variables were most significantly related to radial growth at the study site. Both types of analysis were performed using the DENDROCLIM2002 program (Biondi and Waikul, 2004). Response function analysis yields a rigorous evaluation of climatic effects on tree growth and to reduce the effects resulting from multicollinearity among independent variables (Grissino-Mayer et al., 1989).

The climate parameters were used for climate-growth analysis over the common period with the chronology: 1956-2010 for the climate station, 1950-2002 for CRU grid-boxes, and 1950-2005 for the PDSI grid. Climate variables were lagged to determine if the climate during the previous growing season (beginning of the previous October) affected growth during the current growing season (through current October). The use of lagged climate variables is considered necessary because tree growth is partially dependent upon climatic conditions several months prior to ring formation (Fritts, 1976).

\section{Results}

\subsection{Chronology statistics}

A tree-ring chronology for $S$. saltuaria of 241 years in length, from 1771 to 2011, was constructed (Figure 3(a)). The chronology that began with fewer than five individual tree-ring series was truncated to eliminate weakly replicated portions. The mean segment length, or the average number of rings per core, was 174 years (from 99 to 272 years), a value that set the ceiling for decadal variability retention. The EPS statistic is greater than 0.85 over the period from 1840 to 2011 (Figure 3(c)), indicating that this period had satisfactory quality for the chronology. The EPS threshold corresponded to a sample depth of 30 cores (Figure 3(d)). The mean Rbar (0.36) calculated over a 30-year running window was higher than the $95 \%$ confidence level (0.349), indicating similar year-to-year fluctuations in radial growth indices among trees. The chronology had a slightly high mean sensitivity (0.218) and standard deviation $(0.332 \mathrm{~mm})$, indicating high 


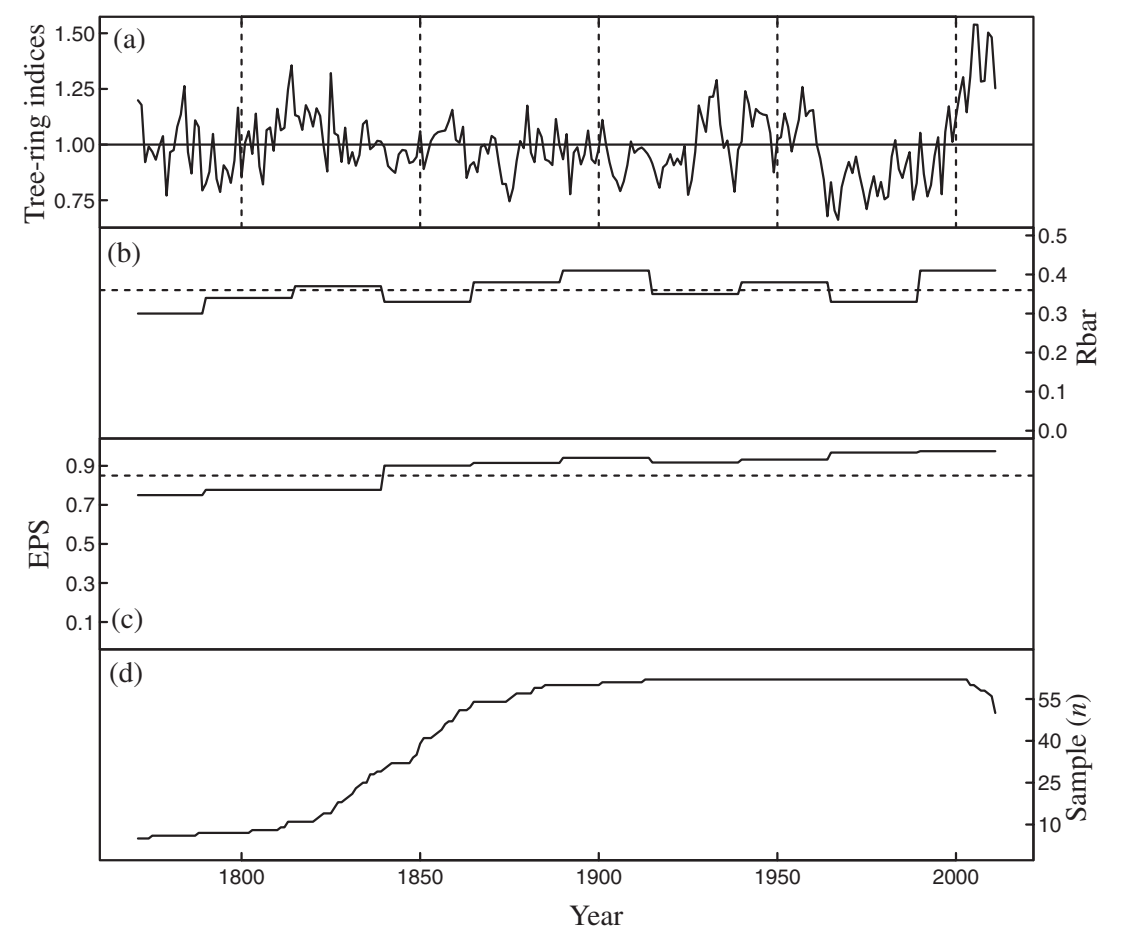

Figure 3. The standard chronology of S. saltuaria from Wolong Natural Reserve, southwestern China. (a) The chronology series, (b) Rbar (dotted line is mean line), (c) EPS (dotted line is 0.85 cut-off value of EPS), and (d) Changing sample size over time.

Table 1. Site information, chronology statistics and results of common interval span analysis of standard tree-ring chronology.

\section{Longitude}

Latitude

Elevation (m)

No. of sample trees

No. of cores

Mean tree width $(\mathrm{mm})$

Standard deviation $(\mathrm{mm})$

Mean sensitivity

Common interval time span

Mean inter-series correlation

Signal-to-noise ratio

Express population signal

Autocorrelation order 1

Variance in first eigenvector $(\%)$

year-to-year fluctuations in radial growth indices (Table 1). The value of $\mathrm{AC} 1$ for the chronology was relatively high (0.69), suggesting that annual growth is affected by the growth of the previous year (biological persistence) (Fritts, 1976). The relatively high level of SNR (9.96) and VFE $(20.43 \%)$ indicated that the trees constituting the mean chronology had strong common signals.

\subsection{Climate-growth response}

The correlation and response analyses with instrumental climate data showed that temperature was most influential in determining annual tree growth (Figure 4). Tree growth indicated highly significant similarities in growth responses to the temperature variables (mean, minimum, and maximum temperatures). The magnitudes of positive correlations were strongest for summer (July) and autumn (September) temperatures, and strong positive correlations were also seen for the temperatures from late winter to early spring (February to April). Precipitation was only weakly correlated with tree growth, and the ring-width record showed negative responses only to summer (June to July) precipitation.

The correlation and response analyses with CRU temperature data exhibited rough similarities to the calculations with instrumental temperature data, but the magnitudes of correlations were apparently lower (Figure 5). The magnitudes of correlations were weaker for precipitation when compared with temperature variables, and the strong relationships seen were the negative correlations with spring (March) and autumn (September) precipitation. Tree growth had significant negative response with PDSI from prior October to current October in the correlation analysis, but only autumn (September to October) PDSI was important in explaining tree growth in the response function analysis (Figure 6).

\subsection{Annual mean temperature reconstruction}

The relationships between the tree-ring chronology and seasonal groupings of climate variables identified annual (prior October to current September) mean instrumental temperature as the most appropriate predictand for reconstruction. The regression model for the calibration period was $Y=1.503 X+13.88$, where $Y=$ annual mean temperature $\left({ }^{\circ} \mathrm{C}\right)$ and $X=$ tree-ring indices. The predictor variable accounted for $54.1 \%$ of the variance of the predictand (Table 2). Our reconstruction paralleled the general 

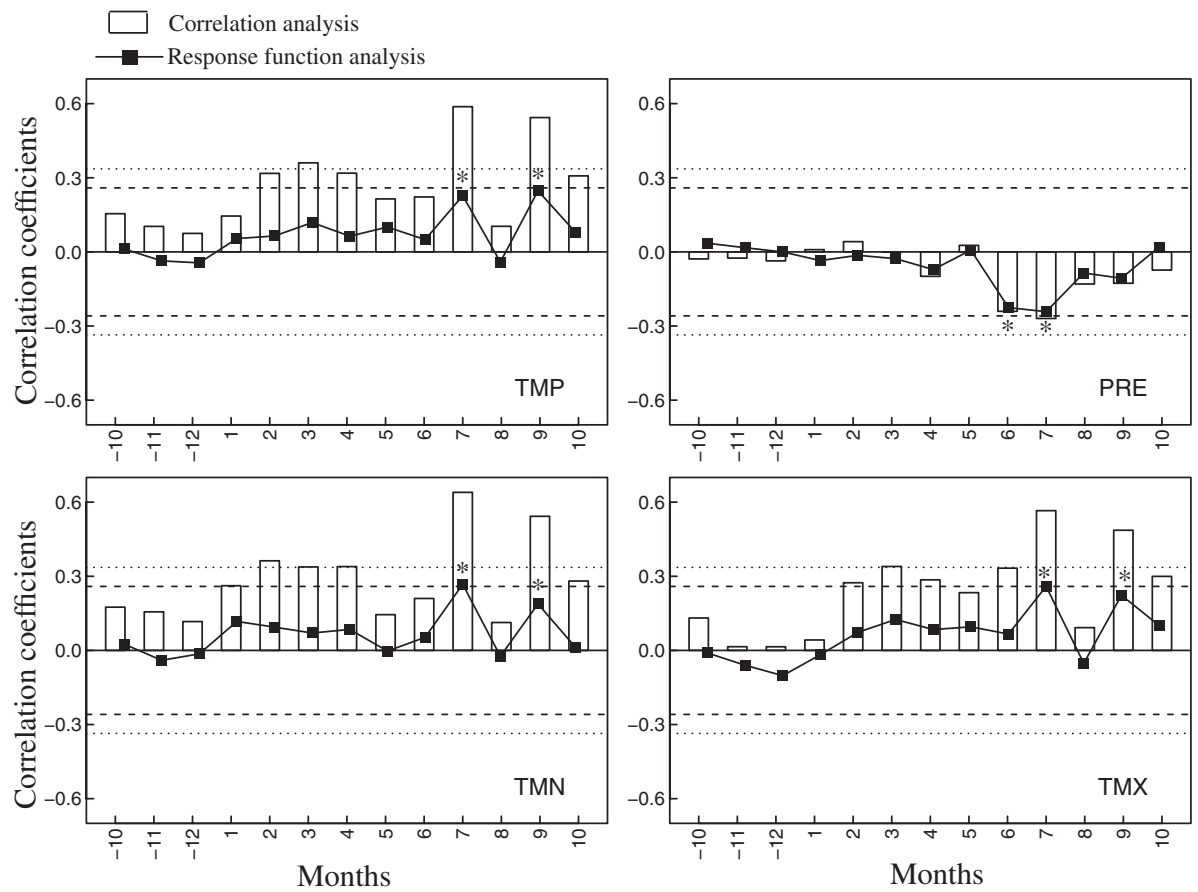

Figure 4. Correlation and response function analyses between meteorological climate data and tree-ring chronology. TMP, PRE, TMN, and TMX represent mean temperature, precipitation, minimum temperature, and maximum temperature, respectively. The dashed and dotted lines represent significant effects at levels of $P<0.05$ and $P<0.01$ for the simple correlation analysis. * over the black boxes represent significant effects at levels of $P<0.05$ for the response function analysis.
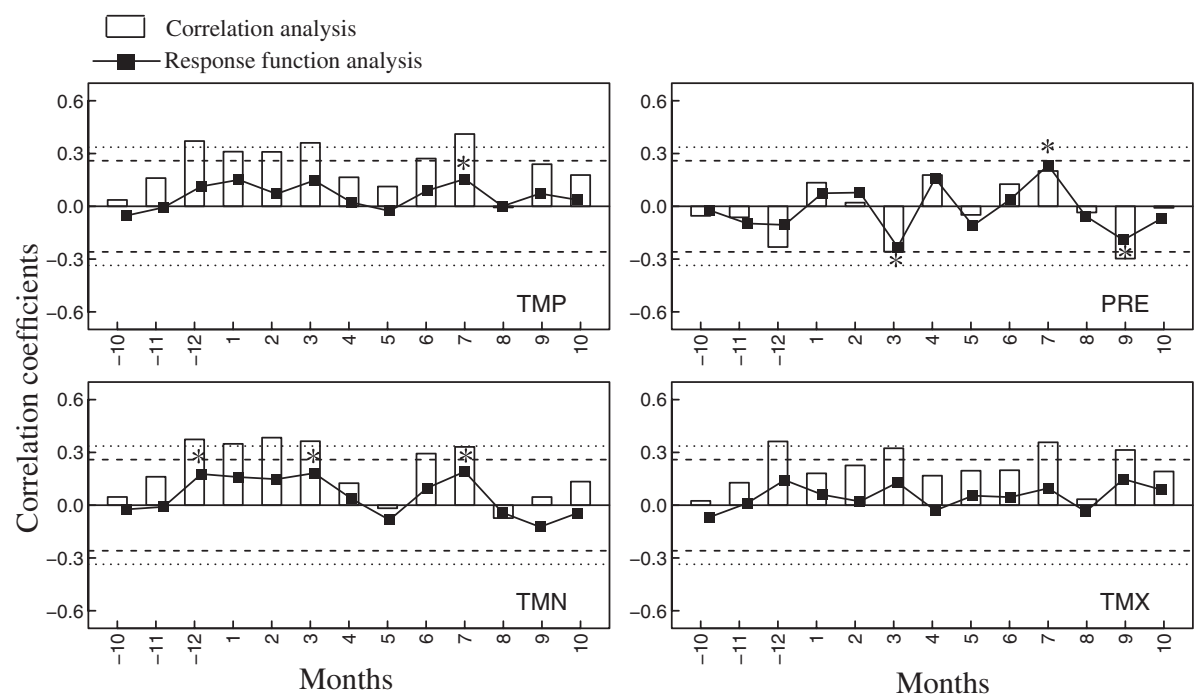

Figure 5. Correlation and response function analyses between CRU gridded climate data and tree-ring chronology. TMP, PRE, TMN, and TMX represent mean temperature, precipitation, minimum temperature, and maximum temperature, respectively. The dashed and dotted lines represent significant effects at levels of $P<0.05$ and $P<0.01$ for the simple correlation analysis. * over the black boxes represent significant effects at levels of $P<0.05$ for the response function analysis.

tendency of the observed temperature (Figure 7(a)) and the leave-one-out cross-validation test showed that reduction of error (RE) was strongly positive, indicating no bias in the calibration/verification exercises. The sign test (ST) and the product mean test (PMT), which describes how well the predicted value tracks the direction of actual data, exceeded the $99 \%$ confidence level. These analyses indicated that the model performed adequately for developing the final reconstruction.
The reconstruction covered 172 years, spanning from 1840 to 2011, beginning on the date at which the EPS value was constantly above the threshold of 0.85 (Figure 7(b)). The reconstruction showed decadal variations and revealed several prolonged warm and cold periods after smoothing with an 11-year moving average filter. The continuous multi-decadal warm periods occurred during the 1927-1960 interval, while other warm periods were considerably shorter in duration and occurred during the 


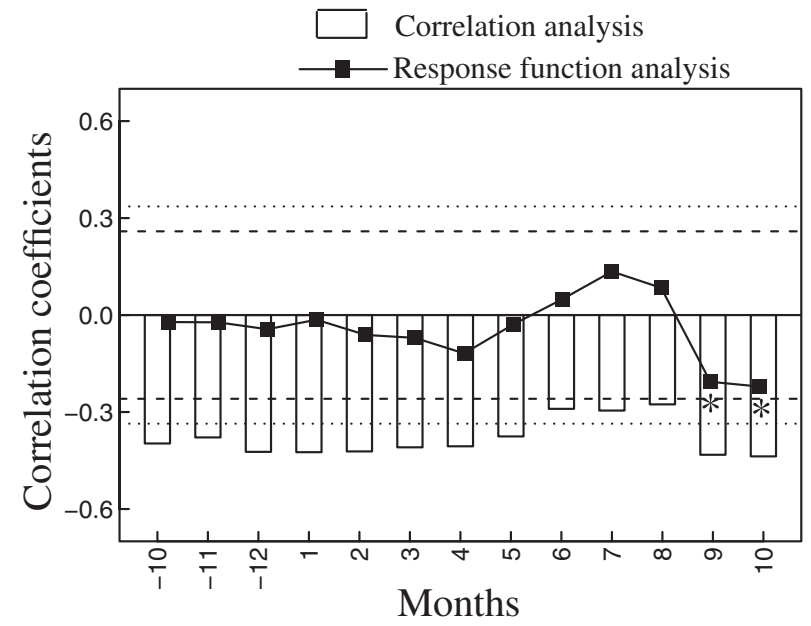

Figure 6. Correlation and response function analyses between PDSI and tree-ring chronology. The dashed and dotted lines represent significant effects at levels of $P<0.05$ and $P<0.01$ for the simple correlation analysis. * below the black boxes represent significant effects at levels of $P<0.05$ for the response function analysis.

Table 2. Leave-one-out cross-validation statistics of climategrowth model for climate reconstruction.

\begin{tabular}{ccccccc}
\hline & $r$ & $r^{2}$ & $r_{\text {adj }}^{2}$ & RE & ST & PMT \\
\hline Calibration & $0.736^{*}$ & $0.541^{*}$ & $0.532^{*}$ & - & - & - \\
Verification & $0.712^{*}$ & $0.508^{*}$ & $0.498^{*}$ & 0.507 & $44+/ 10-^{*}$ & $5.689^{*}$ \\
\hline
\end{tabular}

Note that $r$ is the correlation coefficient, $r^{2}$ is the explained variance, $r_{\text {adj }}{ }^{2}$ is the adjustment explained variance, RE is the reduction of error statistic, $\mathrm{ST}$ is sign test, and PMT is the product mean test. * means the significant level $P<0.01$.

1853-1862 and 1997-2011 intervals. By comparison, the most pronounced cold period lasted for 36 years, occurring during the 1961-1996 interval. Another unusually low temperature was present during the 1886-1926 interval, lasting about 41 years. The reconstruction also had one cold episode in $1863-1882$.

\section{Discussion}

\subsection{The association of tree growth with climate}

High-latitude alpine treelines are generally thought to be limited by temperature (Körner, 1998). At the global scale, the treelines of the world's mountains seem to follow a common isotherm: a seasonal mean ground temperature of $6.7^{\circ} \mathrm{C}$ (Körner and Paulsen, 2004). Most studies of tree-growth-climate interaction at the treeline have reported the fidelity of local summer temperature sensitivity embedded in tree-ring width variability (Esper et al., 2002; Mann et al., 2008). The resulting chronologies have been used to reconstruct either regional or detailed spatial patterns of past temperature variability at various locations (Villalba et al., 2003; Wilson et al., 2007; Fan et al., 2009; Esper et al., 2012; Büntgen et al., 2013). In this study, the tree-ring records show a strong and consistent relationship with summer (July) temperature measurements (Figures 4 and 5). This finding parallels the generally observed tendency of strong temperature controls on tree growth at alpine treelines (Körner and Paulsen, 2004). Calculated from the instrumental data of the Dujiangyan meteorological station (the lapse rate for saturated air of $0.6^{\circ} \mathrm{C}$ per $100 \mathrm{~m}$ ) (Buckley et al., 1997), the minimum (TMN), mean (TMP), and maximum (TMX) temperatures in July of the sample site were $3.52,6.71$, and $10.61^{\circ} \mathrm{C}$, respectively. This result indicates that the thermal conditions in July for $S$. saltuaria stands are below even the threshold temperatures $\left(\mathrm{TMN}=4-5{ }^{\circ} \mathrm{C}, \mathrm{TMP}=8-9{ }^{\circ} \mathrm{C}, \mathrm{TMX}=13-14^{\circ} \mathrm{C}\right)$ at which cell division and differentiation are active for the alpine coniferous forests (Rossi et al., 2008). This provides independent confirmation that summer temperature is a critical factor limiting production and differentiation of xylem cells at the sample site.

The overall positive effect of an increase in autumn (September) temperatures on tree growth could also be related to a direct physiological influence. During the late growing season, radial increments are almost halted, and the storage of carbohydrates may be oriented towards secondary cell wall building, while late cell growing may continue for another several weeks (Schmitt et al., 2000; Bouriaud et al., 2004). Relatively warm climate in autumn can leave enough time to complete secondary wall synthesis and lignin deposition of latewood before winter (Gričar et al., 2005; Rossi et al., 2006), and the completed thickening of wood elements in autumn can decrease the risk of direct frost damage to plant tissues when exposed to cold climate spells in winter (Lazarus et al., 2004; Misson et al., 2004). The high autumn temperatures will benefit the process of cell wall thickening of coniferous trees in several ways, such as by activating enzymes, by increasing the ability of membranes to transport substances, and by decreasing the duration of tracheid development in the secondary thickening zone (Antonova and Stasova, 1997; Lebourgeois et al., 2005).

The chronology yielded several of the significant correlations with temperatures from later winter to early spring (prior December to current March). A warm winter may influence the breaking of dormancy and the resumption of physiological activity in the tree, and thus may increase the duration of the current growing season (Maherali et al., 2004). Furthermore, warm climates in winter can decrease the probability of freezing-induced embolism of the previous year's early wood vessels, which are necessary for the spring recovery of hydraulic conductivity (Cochard et al., 1992; Lebourgeois et al., 2004). Later in the season, a warm early spring can hasten budburst and cambial reactivation after winter dormancy and thus also promote growth (Lebourgeois et al., 2012). Moreover, tree-growth benefits from higher temperatures in early spring, which can make the winter snow cover, melt earlier, making enough moisture available to satisfy the water demand of trees in the early growing season (Vaganov et al., 1999; Fan et al., 2008).

In addition, we found high precipitation and the PDSI generally to have a negative influence on tree growth. This finding indicates that rainy and cloudy weather may 

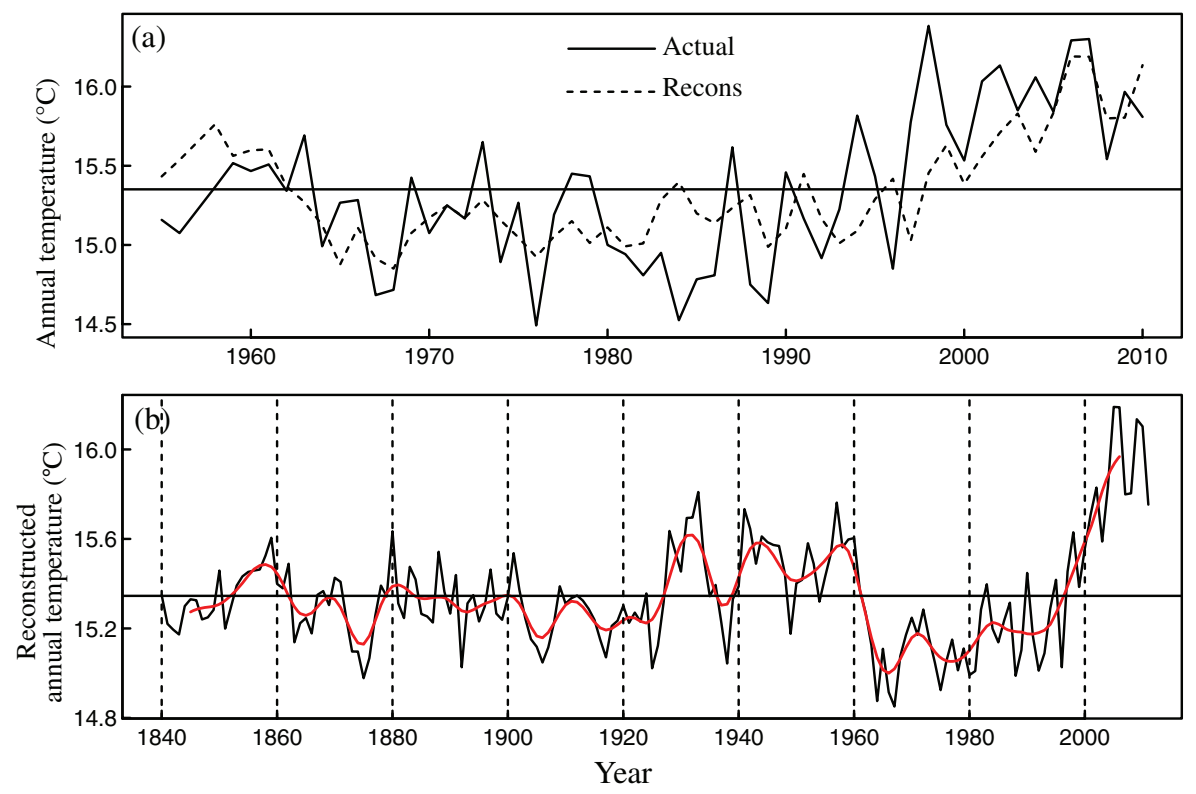

Figure 7. Climate reconstruction in Wolong Natural Reserve, southwestern China. (a) The comparison of actual (solid line) and reconstructed (dashed line) annual mean temperature from 1956 to 2010. (b) Tree-ring reconstruction of annual mean temperature, plotted annually from 1840 to 2011 , along with a smoothed 11-year moving average.

cause an increased risk of delayed snow melt and freezing injury in winter that can inhibit the cambial activity at the beginning of the growing season (Vaganov et al., 1999; Auclair et al., 2010). Furthermore, a pluvial climate in the growing season may result in a low mean temperature, and low air and soil temperatures may limit tree growth by affecting water availability and thus the photosynthetic rate (DeLucia, 1986; Gruber et al., 2009).

\subsection{Changes in reconstructed temperature over time}

We compared our reconstruction with other temperaturesensitive tree-ring records in surrounding regions to identify whether our results can accurately represent large-scale climate features. The positive relationship is most statistically significant for our reconstruction and the winter minimum temperature reconstruction for the Shanuli Mountain of western Sichuan over the period from 1840 to 1989 ( $r=0.544, P<0.01$ ) (Shao and Fan, 1999). This positive relationship may be due to the relatively short distance between the two sampling sites. Our reconstruction also preserves a marked resemblance of decadal-scale temperature variation with summer temperature reconstruction for northwestern Yunnan during the period from 1840-2001 ( $r=0.457, P<0.01$ ) (Li et al., 2011b) and summer temperature reconstruction for the source region of the Yangtze River on the Tibetan Plateau during the period from 1840 to $2002(r=0.467, P<0.01)$ (Liang et al., 2008). The comparisons described above are indicative of the capacity of the reconstruction in this study to capture temperature signal over a well-defined spatial domain.

The climate was relatively stable prior to 1900 , aside from a descending temperature trend that occurred from 1864 to 1882 . This pattern agrees with existing tree-ring temperature proxies for the Gaoligong Mountains of northwestern Yunnan (Fan et al., 2010) and the source region of the Yangtze River on the Tibetan Plateau (Liang et al., 2008). The early 20th century (1900s-1920s) of the reconstruction was characterized by a relatively cold epoch. This temperature depression has also been captured by tree-ring data for the Miyaluo Natural Reserve in western Sichuan analysed by Li et al. (2011a) and for the central Hengdual Mountains analysed by Fan et al. (2009). The reconstruction indicated that temperatures were persistently above average from the 1930s-1950s, a fact also clearly recorded in tree-ring-based temperature reconstructions for the Himalayan region (Yadav et al., 1999; Cook et al., 2003) and the central Hengduan Mountains (Fan et al., 2009; Li et al., 2011b). Based on the multi-proxy materials, Wang et al. (2001) reconstructed the annual temperature series of China over the past millennium and indicated that temperature anomalies in 1920s-1940s were the warmest 30 consecutive years of the 20th century, and that the 1940s were among the warmest decades in southwest China. These results roughly agree with the findings of this study.

By combining instrumental temperature data with long, temperature-sensitive proxy records, Mann et al. (1999, 2008) demonstrated the 20th-century warming to have been abrupt and truly exceptional in the context of at least the past millennium. However, we found that climate warmth in the 20th century is not anomalous in our reconstruction, and the mean temperature $\left(15.3^{\circ} \mathrm{C}\right)$ of the 20th century was even somewhat lower than that of the 19 th century $\left(15.37^{\circ} \mathrm{C}\right)$. Interestingly, the most characteristic feature of the 20th century was an unusual cold spell that occurred during the latter half of this century (1961-1996), and nine of the top ten coldest years took place during this cold period. 
Three major glaciers of the Hengduan Mountains - the Hailuogou Glacier $\left(29.59^{\circ} \mathrm{N}, 101.87^{\circ} \mathrm{E}, 2940 \mathrm{~m}\right)$ of the Gongga Mountain, the Mingyong Glacier $\left(28.43^{\circ} \mathrm{N}\right.$, $98.68^{\circ} \mathrm{E}, 5000 \mathrm{~m}$ ) of the Meili Snow Mountain, and the Baishui No.1 Glacier $\left(27.12^{\circ} \mathrm{N}, 100.2^{\circ} \mathrm{E}, 4800 \mathrm{~m}\right)$ of the Jade Dragon Snow Mountain - all maintained a state of stagnation or speed-down recession during the 1970s-1980s (He et al., 2003), indicating a relative cold climate prevailed on a regional scale. The temperature signal of $\delta^{18} \mathrm{O}$ variations preserved in ice cores recovered from the Puruogangri ice field $\left(33.73-37.73^{\circ} \mathrm{N}\right.$, $88.33-89.83^{\circ} \mathrm{E}, 5500-6500 \mathrm{~m}$ ) in the central Tibetan Plateau also experienced a cold episode from 1975 to 1985 that was exceptionally cold from the perspective of the past 600 years (Yang et al., 2009). Based on tree-ring data for Smith fir (Juniperus tibetica) trees of the central Tibetan Plateau, He et al. (2013) identified a pronounced cold spell over the last five decades (1948-2003) that was comparable to those of any cold period over the past 600 years, including the most pronounced cold spells of the Little Ice Age. An anomalous temperature depression in the late 20th century has been proven to be a determined phenomenon of the temperature-sensitive tree-ring data for the Tibetan Plateau and its adjoining regions (Shao and Fan, 1999; Cook et al., 2003; Bräuning and Mantwill, 2004; Yadav et al., 2004; Liang et al., 2008; Fan et al., 2009; Li et al., 2011b; Wang et al., 2014).

China experienced significant decreases in solar radiation $\left(-4.5 \mathrm{~W} \mathrm{~m}^{-2}\right.$ per decade) over the latter half of the 20th century (Che et al., 2005; Qian et al., 2006), and surface cooling induced by aerosol radiative forcing is at a maximum over the Sichuan Basin of southwest China (Giorgi et al., 2002). A significant decrease in the summertime maximum temperature for a large portion of southeastern China near the Sichuan Basin over this time period has been detected (Kaiser and Qian, 2002). Analysis of meteorological data from the Dujiangyan station reveals that the study area has experienced a significant decrease $\left(-75.76 \mathrm{~h} \mathrm{decade}^{-1}\right)$ in sunshine duration from 1960 to 2000 . The annual mean temperature also decreased $\left(-0.18^{\circ} \mathrm{Cdecade}^{-1}\right)$ for the period from 1960 to 1990 . Decreasing incoming radiation in recent decades of the study area reduces the amount of solar radiation available for photosynthesis, which has negative impact on tree growth (D'Arrigo et al., 2008). These unprecedented adverse climate conditions may have negative impact on forest growth in western Sichuan and its nearby regions during the late 20th century.

The climate has undergone a significant warming trend since the year 1997. The warming rate for the 1997-2011 period was $0.4{ }^{\circ} \mathrm{C}$ decade $^{-1}$, and the mean temperature for this period was $0.44^{\circ} \mathrm{C}$ higher than the mean temperature of the reconstruction. 2005 was the warmest year in the reconstruction with a temperature value of $0.83^{\circ} \mathrm{C}$ higher than the mean value. The surface temperature also caused the year 2005 to be regarded as one of the two warmest years of global instrumental records (Solomon et al., 2007).

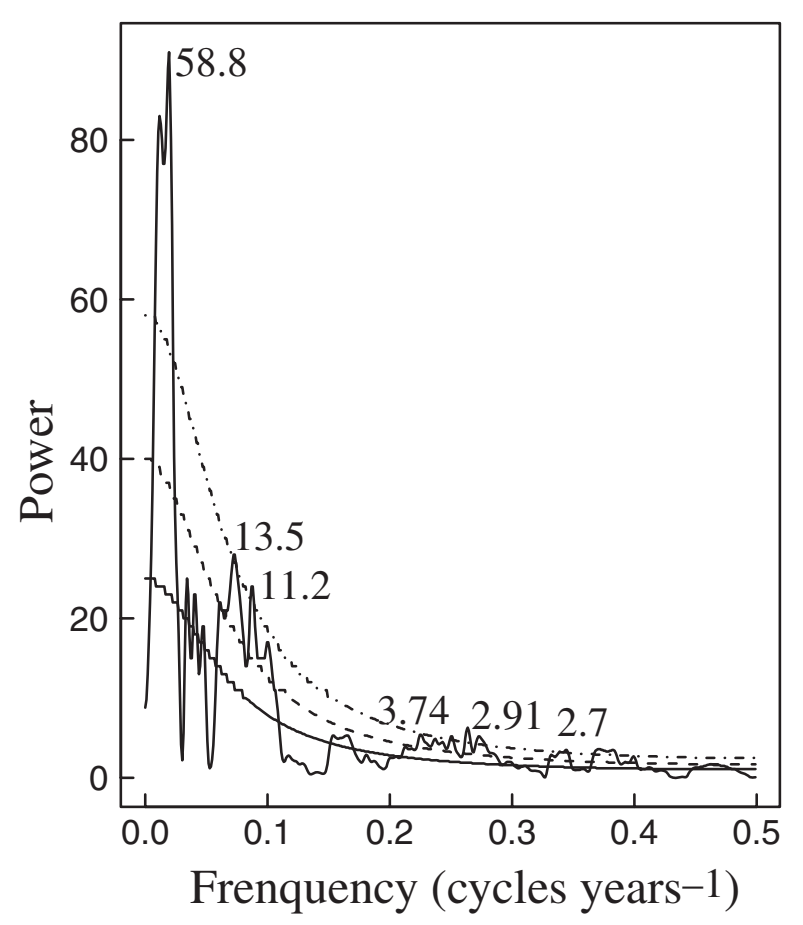

Figure 8. MTM spectral density of the temperature reconstruction. The bold line indicates the null hypothesis; the dash, dash-dot and dotted lines indicate the 90, 95 and $99 \%$ significance level, respectively.

\subsection{Spectral analysis of the reconstruction}

The spectral analysis of reconstruction using multi-taper method (MTM) (Mann and Lees, 1996) had lower frequency peaks at $58.8,13.5$, and 11.2 years, while significant high-frequency peaks at $3.74,2.91$, and 2.7 years (Figure 8). The power spectra in the 58.8-year cycle is strikingly similar to the oscillation time (approximately 60 years) of the Atlantic Multidecadal Oscillation (AMO), which may result in persistent atmospheric circulation and regional climate anomalies in North America and western Europe for years to decades (Sutton and Hodson, 2005; $\mathrm{Hu}$ and Feng, 2012). Using a coupled general circulation model, Chen et al. (2010) indicated that the AMO not only has an impact on the climate in the Atlantic but also induces coupled feedbacks in tropical Pacific regions. A fraction of the ENSO-South Asian monsoon variation on a decadal timescale can be explained by sea surface temperature (SST) anomalies associated with the AMO. Wang et al. (2013) detected the homogeneous pattern of cold/warm anomalies between the AMO and the mainland of China over the course of the past millennium, which had been ascribed to surface heating over the Asian continent, linking the AMO and the Indian summer monsoon.

The significant 13.5- and 11.2-year cycles strongly cohere with the classic 11-year cycle of sunspot activity (Shindell et al., 1999), implying a potential response of the climate system to sun variability. The 11-year period evident in solar activity also appears in tree-ring chronologies of the central Tien Shan area of northwest China (Li et al., 2006), the central Hengduan Mountains (Li et al., 2011b), the western Himalaya Mountains (Singh et al., 2009), and Mongolia (Pederson et al., 2001). The peaks 
corresponding to the periods of $3.74,2.91$, and 2.7 years do fall in the broad spectral peak cycle of 2-8 years (Jones et al., 2001), which characterizes the variability of the El Niño Southern Oscillation (ENSO). This finding suggests that inter-annual temperature variations over the western Sichuan Plateau may be driven by ENSO events. Lu et al. (2012) examined the growth sensitivity of the vegetation of China to ENSO events and found La Niña-sensitive areas to be much smaller than El Niño-sensitive areas. It should be noted that the Hengduan Mountains, including our study region, make up one of the two cores of the El Niño-sensitive areas (Lu et al., 2012). A growing body of evidences suggests a strong teleconnection between the ENSO and the inter-annual variability of tree-ring data for the Tibetan plateau (Fan et al., 2008; Liang et al., 2008; Li et al., 2011b).

\section{Conclusion}

We described the development of a tree-ring width chronology of $S$. saltuaria at the Wolong Natural Reserve in the western Sichuan Plateau of China that is suitable for reconstructing temperature-related climate forcing over the past 172 years (1840-2011). The climate/tree-growth model accounted for $54.1 \%$ of the observed temperature variance during the period from 1955 to 2010. At the decadal scale, the major warm periods of the reconstructed series were 1853-1862, 1927-1960, and 1997-2011. The most dominant cold episodes occurred from 1886 to 1926,1863 to 1882 , and 1961 to 1996 , respectively. Comparisons with other temperature reconstructions from surrounding areas provide us with a high degree of confidence in our reconstruction. Spectral analysis revealed the distinct cycles at multi-decadal (58.8 years), decadal (13.5 and 11.2 years), and inter-annual (2-8) scales, which characterized the variability of AMO, solar activity, and ENSO, respectively. This reconstruction adds to the development of a multi-species tree-ring network in the western Sichuan Plateau that enables us to gain deeper insight into this region's climate history.

\section{Acknowledgements}

This research was supported by Natural Science Foundation of China (Grant Nos. 31000210 and 41071039). We greatly thank Hong-Yan Qiu and Cai-Yun Liu of the Tree-Ring Laboratory, Institute of Botany, Chinese Academy of Sciences for the assistance of ring-width measurement. We are also indebted to Yi-He Lv, Xiao-Ming Feng, and Li-Xin Lv for providing insightful comments and constructive suggestions for revising an early draft of this article. The study was prompted by the field assistance received from Institute of Ecology, Sichuan Forestry Research Academy.

\section{References}

An L, Liu JG, Ouyang ZY, Linderman M, Zhou SQ, Zhang HM. 2001. Simulating demographic and socioeconomic processes on household level and implications for giant panda habitats. Ecol. Model. 140: 31-49, doi: 10.1016/S0304-3800(01)00267-8.

Antonova GF, Stasova VV. 1997. Effects of environmental factors on wood formation in larch (Larix sibirica Ldb.) stems. Trees-Struct. Funct. 11: 462-468, doi: 10.1007/P100009687.

Auclair AND, Heilman WE, Brinkman B. 2010. Predicting forest dieback in Maine, USA: a simple model based on soil frost and drought. Can. J. Forest Res. 40: 687-702, doi: 10.1139/X10-023.

Biondi F, Waikul K. 2004. DENDROCLIM2002: a C++ program for statistical calibration of climate signals in tree-ring chronologies. Comput. Geosci. 30: 303-311, doi: 10.1016/j.cageo.2003.11.004.

Bouriaud O, Breda N, Le Moguedec G, Nepveu G. 2004. Modelling variability of wood density in beech as affected by ring age, radial growth and climate. Trees-Struct. Funct. 18: 264-276, doi: 10.1007/s00468-003-0303-x.

Bräuning A. 2001. Climate history of the Tibetan Plateau during the last 1000 years derived from a network of Juniper chronologies. Dendrochronologia 19: 127-137.

Bräuning A, Mantwill B. 2004. Summer temperature and summer monsoon history on the Tibetan Plateau during the last 400 years recorded by tree rings. Geophys. Res. Lett. 31: L24205, doi: 10.1029/2004GL020793.

Buckley BM, Cook ER, Peterson MJ, Barbetti M. 1997. A changing temperature response with elevation for Lagarostrobos franklinii in Tasmania, Australia. Clim. Change 36: 477-498, doi: 10.1023/A:1005322332230.

Büntgen U, Kyncl T, Ginzler C, Jacks DS, Esper J, Tegel W, Heussner KU, Kyncl J. 2013. Filling the Eastern European gap in millennium-long temperature reconstructions. Proc. Natl. Acad. Sci. U. S. A. 110: 1773-1778, doi: 10.1073/pnas.1211485110.

Che HZ, Shi GY, Zhang XY, Arimoto R, Zhao JQ, Xu L, Wang B, Chen ZH. 2005. Analysis of 40 years of solar radiation data from China, 1961-2000. Geophys. Res. Lett. 32: L06803, doi: 10.1029/2004GL022322.

Chen W, Dong BW, Lu RY. 2010. Impact of the Atlantic Ocean on the multidecadal fluctuation of El Niño-Southern Oscillation-South Asian monsoon relationship in a coupled general circulation model. J. Geophys. Res. Atmos. 115: D17109, doi: 10.1029/2009jd013596.

Cochard H, Breda N, Granier A, Aussenac G. 1992. Vulnerability to air-embolism of three European oak species (Quercus petraea (Matt) Liebl, Quercus pubescens Willd, Quercus robur L). Ann. des Sci. Forestieres 49: 225-233, doi: 10.1051/forest:19920302.

Cook ER, Kairiukstis LA. 1990. Methods of Dendrochronology: Applications in the Environmental Sciences. Kluwer Academic Publishers: Dordrecht, The Netherlands.

Cook ER, Krusic PJ, Jones PD. 2003. Dendroclimatic signals in long tree-ring chronologies from the Himalayas of Nepal. Int. J. Climatol. 23: 707-732, doi: 10.1002/Joc.911.

Cook ER, Anchukaitis KJ, Buckley BM, D’Arrigo RD, Jacoby GC, Wright WE. 2010. Asian monsoon failure and megadrought during the last millennium. Science 328: 486-489, doi: $10.1126 /$ science. 1185188 .

Cui J, An SQ, Xu Z, Xu Q, Wang ZS, Liu SR. 2005. Isotopic characteristics of precipitation and throughfall of alpine shrubs on Balang mountains in Wolong. J. Nat. Resour. 20: 660-668.

Dai A, Trenberth KE, Qian TT. 2004. A global dataset of Palmer Drought Severity Index for 1870-2002: relationship with soil moisture and effects of surface warming. J. Hydrometeorol. 5: 1117-1130, doi: 10.1175/Jhm-386.1.

D’Arrigo R, Wilson R, Liepert B, Cherubini P. 2008. On the 'divergence problem' in northern forests: a review of the tree-ring evidence and possible causes. Glob. Planet. Change 60: 289-305, doi: 10.1016/j.gloplacha.2007.03.004.

DeLucia EH. 1986. Effect of low root temperature on net photosynthesis, stomatal conductance and carbohydrate concentration in Engelmann spruce (Picea engelmannii Parry) seedlings. Tree Physiol. 2: 143-154.

Esper J, Cook ER, Schweingruber FH. 2002. Low-frequency signals in long tree-ring chronologies and the reconstruction of past temperature variability. Science 295: 2250-2253, doi: 10.1126/science.1066208.

Esper J, Büntgen U, Timonen M, Frank DC. 2012. Variability and extremes of northern Scandinavian summer temperatures over the past two millennia. Glob. Planet. Change 88-89: 1-9, doi: 10.1016/j.gloplacha.2012.01.006.

Fan ZX, Bräuning A, Cao KF. 2008. Tree-ring based drought reconstruction in the central Hengduan Mountains region (China) since AD 1655. Int. J. Climatol. 28: 1879-1887, doi: 10.1002/Joc.1689.

Fan ZX, Bräuning A, Yang B, Cao KF. 2009. Tree ring density-based summer temperature reconstruction for the central Hengduan 
Mountains in southern China. Glob. Planet. Change 65: 1-11, doi: 10.1016/j.gloplacha.2008.10.001.

Fan ZX, Bräuning A, Tian QH, Yang B, Cao KF. 2010. Tree ring recorded May-August temperature variations since AD 1585 in the Gaoligong Mountains, southeastern Tibetan Plateau. Palaeogeogr. Palaeoclimatol. Palaeoecol. 296: 94-102, doi: 10.1016/ j.palaeo.2010.06.017.

Fritts HC. 1976. Tree Rings and Climate. Academic Press: New York, NY.

Fu BJ, Wang KL, Lu YH, Liu SL, Ma KM, Chen LD, Liu GH. 2004. Entangling the complexity of protected area management: the case of Wolong Biosphere Reserve, southwestern China. Environ. Manage. 33: 788-798, doi: 10.1007/s00267-004-0043-8.

Giorgi F, Bi XQ, Qian Y. 2002. Direct radiative forcing and regional climatic effects of anthropogenic aerosols over East Asia: a regional coupled climate-chemistry/aerosol model study. J. Geophys. Res. Atmos. 107: 4439, doi: 10.1029/2001JD001066.

Gričar J, Čufar K, Oven P, Schmitt U. 2005. Differentiation of terminal latewood tracheids in silver fir during autumn. Ann. Bot. 95: 959-965, doi: 10.1093/Aob/Mci112.

Grissino-Mayer HD. 2001. Evaluating crossdating accuracy: a manual and tutorial for the computer program COFECHA. Tree-Ring Res. 57: $205-221$.

Grissino-Mayer HD. 2003. A manual and tutorial for the proper use of an increment borer. Tree-Ring Res. 59: 63-79.

Grissino-Mayer HD, Rosenberger MS, Butler DR. 1989. Climatic response in tree rings of loblolly pine from north Georgia. Phys. Geogr. 10: $32-43$.

Gruber A, Wieser G, Oberhuber W. 2009. Intra-annual dynamics of stem $\mathrm{CO}_{2}$ efflux in relation to cambial activity and xylem development in Pinus cembra. Tree Physiol. 29: 641-649, doi: 10.1093/treephys/tpp001.

Guo QQ, Lu J, Luo DQ, Fang JP, Wang ZH. 2010. Ecological characteristics of Sabina saltuaria population at the timberline ectone on the sunny slope of the Sejila Mountain. J. Northwest Forestry Univ. 25: $15-18$.

He YQ, Zhang ZL, Yao TD, Chen T, Pang HX, Zhang D. 2003. Modern changes of the climate and glaciers in China's monsoonal temperate-glacier region. Acta Geogr. Sin. 58: 551-558.

He GM, Chen XD, Bearer S, Colunga M, Mertig A, An L, Zhou SQ, Linderman M, Ouyang ZY, Gage S, Li SX, Liu JG. 2009. Spatial and temporal patterns of fuelwood collection in Wolong Nature Reserve: implications for panda conservation. Landsc. Urban Plan. 92: 1-9, doi: 10.1016/j.landurbplan.2009.06.012.

He MH, Yang B, Datsenko NM. 2013. A six hundred-year annual minimum temperature history for the central Tibetan Plateau derived from tree-ring width series. Clim. Dyn. 43: 641-655, doi: 10.1007/s00382-013-1882-x.

Holmes RL. 1983. Computer-assisted quality control in tree-ring dating and measurement. Tree-Ring Bull. 43: 69-78.

$\mathrm{Hu}$ Q, Feng S. 2012. AMO- and ENSO-driven summertime circulation and precipitation variations in North America. J. Clim. 25: 6477-6495, doi: 10.1175/Jcli-D-11-00520.1.

Jones PD, Osborn TJ, Briffa KR. 2001. The evolution of climate over the last millennium. Science 292: 662-667, doi: 10.1126/science.1059126.

Kaiser DP, Qian Y. 2002. Decreasing trends in sunshine duration over China for 1954-1998: indication of increased haze pollution? Geophys. Res. Lett. 29: 2042, doi: 10.1029/2002GL016057.

Körner C. 1998. A re-assessment of high elevation treeline positions and their explanation. Oecologia 115: 445-459, doi: $10.1007 / \mathrm{s} 004420050540$.

Körner C, Paulsen J. 2004. A world-wide study of high altitude treeline temperatures. J. Biogeogr. 31: 713-732.

Lazarus BE, Schaberg PG, DeHayes DH, Hawley GJ. 2004. Severe red spruce winter injury in 2003 creates unusual ecological event in the northeastern United States. Can. J. Forest Res. 34: 1784-1788, doi: 10.1139/X04-122

Lebourgeois F, Cousseau G, Ducos Y. 2004. Climate-tree-growth relationships of Quercus petraea Mill. stand in the Forest of Berce ("Futaie des Clos", Sarthe, France). Ann. For. Sci. 61: 361-372, doi: 10.1051/forest:2004029.

Lebourgeois F, Breda N, Ulrich E, Granier A. 2005. Climate-tree-growth relationships of European beech (Fagus sylvatica L.) in the French Permanent Plot Network (RENECOFOR). Trees-Struct. Funct. 19: 385-401, doi: 10.1007/s00468-004-0397-9.

Lebourgeois F, Merian P, Courdier F, Ladier J, Dreyfus P. 2012. Instability of climate signal in tree-ring width in Mediterranean mountains: a multi-species analysis. Trees-Struct. Funct. 26: 715-729, doi: 10.1007/s00468-011-0638-7.

Li JB, Gou XH, Cook ER, Chen FH. 2006. Tree-ring based drought reconstruction for the central Tien Shan area in northwest China. Geophys. Res. Lett. 33: L07715, doi: 10.1029/2006gl025803.

Li ZS, Liu GH, Fu BJ, Zhang QB, Hu CJ, Luo SZ. 2011a. Tree ring-based summer temperature reconstruction over the past 200 years in Miyaluo of western Sichuan, China. Quat. Sci. 31: 1-13.

Li ZS, Shi CM, Liu YB, Zhang JL, Zhang QB, Ma KP. 2011b. Summer mean temperature variation from 1710-2005 inferred from tree-ring data of the Baimang Snow Mountains, northwestern Yunnan, China Clim. Res. 47: 207-218, doi: 10.3354/Cr01012.

Liang EY, Shao XM, Qin NS. 2008. Tree-ring based summer temperature reconstruction for the source region of the Yangtze River on the Tibetan Plateau. Glob. Planet. Change 61: 313-320.

Liu JG, Linderman M, Ouyang ZY, An L, Yang J, Zhang HM. 2001 Ecological degradation in protected areas: the case of Wolong Nature Reserve for giant pandas. Science 292: 98-101, doi: 10.1126/science. 1058104 .

Liu XL, Hao XD, Yang DS, Liu SR, Su YM, Cai XH, He F, Ma QY. 2006. Aboveground biomass and it's models of Quercus aquifolioides thicket community in Balangshan Mountain in Wolong Natural Reserve. Chin. J. Ecol. 25: 487-491.

Lu A, Zhu W, Jia S. 2012. Assessment of the sensitivity of vegetation to El Niño /Southern Oscillation events over China. Adv. Space Res. 50: 1362-1373, doi: 10.1016/j.asr.2012.06.033.

Maherali H, Pockman WT, Jackson RB. 2004. Adaptive variation in the vulnerability of woody plants to xylem cavitation. Ecology $\mathbf{8 5}$ 2184-2199, doi: 10.1890/02-0538.

Mann ME, Lees JM. 1996. Robust estimation of background noise and signal detection in climatic time series. Clim. Change 33: 409-445, doi: 10.1007/Bf00142586.

Mann ME, Bradley RS, Hughes MK. 1999. Northern hemisphere temperatures during the past millennium: inferences, uncertainties, and limitations. Geophys. Res. Lett. 26: 759-762, doi: 10.1029/1999g1900070.

Mann ME, Zhang ZH, Hughes MK, Bradley RS, Miller SK, Rutherford S, Ni FB. 2008. Proxy-based reconstructions of hemispheric and global surface temperature variations over the past two millennia. Proc. Natl. Acad. Sci. U. S. A. 105: 13252-13257, doi: 10.1073/pnas.0805721105

Marcott SA, Shakun JD, Clark PU, Mix AC. 2013. A reconstruction of regional and global temperature for the past 11,300 years. Science 339: 1198-1201, doi: 10.1126/science.1228026.

Misson L, Rathgeber C, Guiot J. 2004. Dendroecological analysis of climatic effects on Ouercus petraea and Pinus halepensis radial growth using the process-based MAIDEN model. Can. J. For. Res. 34: 888-898, doi: 10.1139/X03-253

Mitchell TD, Jones PD. 2005. An improved method of constructing a database of monthly climate observations and associated high-resolution grids. Int. J. Climatol. 25: 693-712, doi 10.1002/Joc. 1181

Orvis KH, Grissino-Mayer HD. 2002. Standardizing the reporting of abrasive papers used to surface tree-ring samples. Tree-Ring Res. $\mathbf{5 8}$ 47-50.

Osborn TJ, Briffa KR, Jones PD. 1997. Adjusting variance for sample-size in tree-ring chronologies and other regional mean timeseries. Dendrochronologia 15: 89-99.

Pederson N, Jacoby GC, D'Arrigo RD, Cook ER, Buckley BM, Dugarjav C, Mijiddorj R. 2001. Hydrometeorological reconstructions for northeastern Mongolia derived from tree rings: 1651-1995. J. Clim. 14: 872-881, doi: 10.1175/1520-0442(2001)014<0872:Hrfnmd > 2.0.Co;2.

Qian Y, Kaiser DP, Leung LR, Xu M. 2006. More frequent cloud-free sky and less surface solar radiation in China from 1955 to 2000 Geophys. Res. Lett. 33: L01812, doi: 10.1029/2005GL024586.

Qin NS, Shi XH, Shao XM, Wang QC. 2008. Average maximum temperature change recorded by tree rings in west Sichuan plateau. Plateau Mountain Meteorol. Res. 28: 18-24.

Rossi S, Deslauriers A, Anfodillo T, Morin H, Saracino A, Motta R, Borghetti M. 2006. Conifers in cold environments synchronize maximum growth rate of tree-ring formation with day length. New Phytol. 170: 301-310, doi: 10.1111/j.1469-8137.2006.01660.x.

Rossi S, Deslauriers A, Gricar J, Seo JW, Rathgeber CBK, Anfodillo T, Morin H, Levanic T, Oven P, Jalkanen R. 2008. Critical temperatures for xylogenesis in conifers of cold climates. Glob. Ecol. Biogeogr. 17: 696-707, doi: 10.1111/j.1466-8238.2008.00417.x.

Schmitt U, Moller R, Eckstein D. 2000. Seasonal wood formation dynamics of beech (Fagus sylvatica L.) and black locust (Robinia 
pseudoacacia L.) as determined by the "pinning" technique. J. Appl. Bot. 74: 10-16.

Schweingruber FH. 1996. Tree Rings and Environment. Dendroecology. Haupt: Bern, Switzerland.

Shao XM, Fan JM. 1999. Past climate on west Sichuan Plateau as reconstructed from ring-widths of Dragon Spruce. Quat. Sci. 19 $81-89$.

Shao X, Xu Y, Yin ZY, Liang E, Zhu H, Wang S. 2010. Climatic implications of a 3585-year tree-ring width chronology from the northeastern Qinghai-Tibetan Plateau. Quat. Sci. Rev. 29: 2111-2122, doi: 10.1016/j.quascirev.2010.05.005.

Shindell D, Rind D, Balachandran N, Lean J, Lonergan P. 1999. Solar cycle variability, ozone, and climate. Science 284: 305-308, doi: 10.1126/science.284.5412.305.

Singh J, Yadav RR, Wilmking M. 2009. A 694-year tree-ring based rainfall reconstruction from Himachal Pradesh, India. Clim. Dyn. 33 1149-1158, doi: 10.1007/s00382-009-0528-5.

Solomon S, Qin D, Manning M, Chen Z, Marquis M, Averyt KB, Tignor M, Miller HL. 2007. Climate Change 2007: The Physical Science Basis. Cambridge University Press: Cambridge, UK and New York, NY, 237-239.

Song AY, Liu SR, Shi ZM, Dong LS. 2006. Quantitative classification and ordination of subalpine meadow in Wolong Natural Reserve. Chin. J. Appl. Ecol. 17: 1174-1178.

Song HM, Liu Y, Ni WM, Cai QF, Sun JY, Ge WB, Xiao WY. 2007. Winter mean lowest temperature derived from tree-ring width in Jiuzhaigou Region, China since 1750 AD. Quat. Sci. 27 486-491.

Stern DI, Kaufmann RK. 2014. Anthropogenic and natural causes of climate change. Clim. Change 122: 257-269, doi: 10.1007/s10584-013-1007-x.

Sutton RT, Hodson DLR. 2005. Atlantic Ocean forcing of North American and European summer climate. Science 309: 115-118, doi: 10.1126/science.1109496.

Taylor AH, Qin ZS. 1988. Tree replacement patterns in subalpine Abies-Betula forests, Wolong Natural Reserve, China. Vegetation $\mathbf{7 8}$ : 141-149, doi: 10.1007/Bf00033423.

Taylor AH, Reid DG, Qin ZS, Hu JC. 1991. Spatial patterns and environmental associates of bamboo (Bashania-Fangiana Yi) after mass-flowering in southwestern China. Bull. Torrey Bot. Club 118 247-254, doi: 10.2307/2996639.

Vaganov EA, Hughes MK, Kirdyanov AV, Schweingruber FH, Silkin PP. 1999. Influence of snowfall and melt timing on tree growth in subarctic Eurasia. Nature 400: 149-151.

Villalba R, Lara A, Boninsegna JA, Masiokas M, Delgado S, Aravena JC, Roig FA, Schmelter A, Wolodarsky A, Ripalta A. 2003. Large-scale temperature changes across the southern Andes: 20th-century variations in the context of the past 400 years. Clim. Change 59: 177-232, doi: 10.1023/A:1024452701153.

Wang SW, Gong DY, Zhu JH. 2001. Twentieth-century climatic warming in China in the context of the Holocene. Holocene 11: 313-321, doi: 10.1191/095968301673172698.
Wang JL, Yang B, Ljungqvist FC, Zhao Y. 2013. The relationship between the Atlantic Multidecadal Oscillation and temperature variability in China during the last millennium. J. Quat. Sci. 28: 653-658, doi: 10.1002/Jqs.2658.

Wang JL, Yang B, Qin C, Kang SY, He MH, Wang ZY. 2014. Tree-ring inferred annual mean temperature variations on the southeastern Tibetan Plateau during the last millennium and their relationships with the Atlantic Multidecadal Oscillation. Clim. Dyn. 43: 627-640, doi: 10.1007/s00382-00013-01802-00380.

Wigley TML, Briffa KR, Jones PD. 1984. On the average value of correlated time-series, with applications in dendroclimatology and hydrometeorology. J. Clim. Appl. Meteorol. 23: 201-213, doi: 10.1175/1520-0450(1984)023<0201: Otavoc > 2.0.Co; 2 .

Wilson R, Wiles G, D'Arrigo R, Zweck C. 2007. Cycles and shifts: 1,300 years of multi-decadal temperature variability in the Gulf of Alaska. Clim. Dyn. 28: 425-440, doi: 10.1007/s00382-006-0194-9.

Wu P, Wang LL, Shao XM. 2008. Reconstruction of summer temperature variation from maximum density of alpine pine during 1917-2002 for west Sichuan Plateau, China. J. Geogr. Sci. 18: 201-210.

Yadav RR, Park WK, Bhattacharyya A. 1999. Spring-temperature variations in western Himalaya, India, as reconstructed from tree-rings: AD 1390-1987. Holocene 9: 85-90, doi: 10.1191/095968399667529322.

Yadav RR, Park WK, Singh J, Dubey B. 2004. Do the western Himalayas defy global warming? Geophys. Res. Lett. 31: L17201, doi: 10.1029/2004gl020201.

Yang B, Bräuning A, Shi YF. 2003. Late Holocene temperature fluctuations on the Tibetan Plateau. Quat. Sci. Rev. 22: 2335-2344, doi: 10.1016/S0277-3791(03)00132-X.

Yang B, Bräuning A, Liu JJ, Davis ME, Yajun S. 2009. Temperature changes on the Tibetan Plateau during the past 600 years inferred from ice cores and tree rings. Glob. Planet. Change 69: 71-78, doi: 10.1016/j.gloplacha.2009.07.008.

Yang B, Qin C, Huang K, Fan ZX, Liu JJ. 2010. Spatial and temporal patterns of variations in tree growth over the northeastern Tibetan Plateau during the period ad 1450-2001. Holocene 20: 1235-1245, doi: 10.1177/0959683610371997.

Yang B, Qin C, Wang JL, He MH, Melvin TM, Osborn TJ, Briffa KR. 2014. A 3,500-year tree-ring record of annual precipitation on the northeastern Tibetan Plateau. Proc. Natl. Acad. Sci. U. S. A. 111: 2903-2908, doi: 10.1073/pnas.1319238111.

Yu SL, Yuang YJ, Wei WS, Zhang TW, Shang HM, Chen F. 2012. Reconstructed mean temperature in Mearkang, west Sichuan in July and its detection of climatic period signal. Plateau Meteorol. 31: $193-200$.

Zhang QB, Cheng GD, Yao TD, Kang XC, Huang JG. 2003. A 2,326-year tree-ring record of climate variability on the northeastern Qinghai-Tibetan Plateau. Geophys. Res. Lett. 30: 1739, doi: 10.1029/2003gl017425.

Zhang QY, Zhang YC, Luo P, Wang Q, Wu N. 2007. Ecological characteristics of Sabina saltuaria population at timberline on the south-facing slope of Baima Snow Mountain, southwest China. J. Plant Ecol. 31: 857-864. 